Jpn. J. Pharm. Health Care Sci.

一般論文 34(1) 20 - 25 (2008)

\title{
心蔵血管造影剂による急性腎機能低下に対する アセチルシステインの予防効果および製斉の評価
}

清川真美 $^{* 1}$, 澤口利香 ${ }^{1}$, 須田範行 ${ }^{1}$, 武隈 洋 $^{2}$, 菅原 満 $^{1}$, 相馬孝光 ${ }^{3}$, 川嶋 望 $^{3}$, 筒井裕之 ${ }^{3}$, 井関 健 $^{12}$ 北海道大学病院薬斉部 ${ }^{1}$ 北海道大学大学院薬学研究院 ${ }^{2}$ 北海道大学病院循環器科 ${ }^{3}$

\section{Protective Effect of Acetylcysteine against Acute Renal Dysfunction Caused by Radiographic Contrast Media and Evaluation of Acetylcysteine Jelly Preparation}

Masami Kiyokawa* ${ }^{*}$, Rika Sawaguchi ${ }^{1}$, Noriyuki Suda ${ }^{1}$, Yoh Takekuma ${ }^{2}$, Mitsuru Sugawara ${ }^{1}$,

Takamitsu Souma ${ }^{3}$, Nozomu Kawashima ${ }^{3}$, Hiroyuki Tsutsui ${ }^{3}$ and Ken Iseki ${ }^{1,2}$

Department of Pharmacy, Hokkaido University Hospital ${ }^{1}$

Faculty of Pharmaceutical Sciences, Hokkaido University ${ }^{2}$

Department of Cardiovascular Medicine, Hokkaido University Hospital ${ }^{3}$

$\left[\begin{array}{l}\text { Received March 16, } 2007 \\ \text { A ccepted October 26, } 2007\end{array}\right]$

Though $\mathrm{N}$-acetylcysteine (NAC), an antioxidant, has been used to prevent radio-contrast-induced nephropathy (RCIN), the effectiveness of using it remains unclear as the results of studies regarding its protective effect have been inconsistent. Since oral solutions of NAC have an unpleasant smell and taste, we previously developed a jelly preparation of NAC and in the present study, conducted a questionnaire survey to evaluate its user friendliness. The results of the survey indicated that the jelly preparation was effective in masking the unpleasant smell and taste. We also retrospectively examined the effectiveness of NAC in protecting against RCIN. Sixteen percent of patients in our control group $(n=81$, no NAC) developed RCIN, whereas none of the patients in the NAC-treated group $(n=67)$ developed it. RCIN was defined as a greater than $25 \%$ increase in serum creatinine level occurring within 48 hours of exposure to a contrast medium. The results of this study showed that NAC has a protective effect against RCIN even in patients with a high risk of renal dysfunction, including those with diabetes or hypertension as well as those in whom high osmolarity contrast media are used.

Key words — N-acetylcysteine, jelly, radio-contrast-induced nephropathy, acute renal failure

緒言

ヨード造影斉は，血管造影やCT 造影などで必要不可 欠であるが, 造影剂腎症と呼ばれる急性の腎不全を引き 起こすことが知られている，弚の原因として，造影剤に よるエンドセリンやアデノシンの放出の誘導 , 腎血行動 態の変化や活性酸素生成による尿細管上皮細胞への直接 毒性か報告されている ${ }^{12)}$. 造影剤による腎障害の最大の
治療は予防にあるといわれており，乥の方法の一つとし て, 活性酸素による組織障害を防ぐ酸化防止剂である Nアセチルシステイン(以下，NAC と略す)が投与されてき た ${ }^{1-5)}$. しかし，弚の予防効果については報告によって 異なっており，有効性が明らかにされるに至っていな い、また，NACには硫黄臭の特異なにおいがあり，味 は塩辛くえぐみがある゙ことから，患者にとって光の服 用は苦痛であることが予想された .

われわれは以前，においや味を改善した服用しやすい 
製剂を開発しだ，今回は本製剂を服用した患者を対象 にアンケート調査を実施し, 服用感を評価するととも に，弚の造影剂腎症に対するNAC の予防効果を，血清 クレアチニン值の変化率や造影闵腎症の発症数などを用 いて検討したので報告する

\section{対象}

2003 年 8 月から 2006 年 8 月までに北海道大学病院循 環器科に入院した患者において，2004年 8月 1日から 2006 年 8 月 31 日の間に造影剂投与による腎障害予防の ためにNAC を投与した 67 名をNAC 群，光れ以前の 1 年間に検査を施行した患者 81 名を対照群として評価し た。なお，NACの腎障害予防を目的とした使用に関し ては, 北海道大学医学部医の倫理委員会での承認を得た 上で, 患者にはインフォームドコンセントを行い，同意 を得ている。

\section{方法}

\section{1. 投与方法}

NAC 投与群は, 検査(造影剂投与)当日に 1 回 $600 \mathrm{mg}$ を1日 2 回投与とし，1回目にゼラチンを基剤とした NACゼリ一製剤を，2回目にNAC 液を服用した。

NAC ゼリーおよびNAC 液の製剂組成を表 1 に示す． NAC は市販の内用液斉(アセチルシステイン内用液 ${ }^{\circledR} 17.6$ \%，千寿製薬(株))を，ゲル化斉はゼラチン(国産の豚皮， 平均分子量約 10 万, ゼライス ${ }^{\circledR}$ ，マルハ(株))を用いた。 矯味剂にはアミノレバン $\mathrm{EN}^{\circledR}$ 専用フレーバーミックス (大塚製薬(株))を用いた。

NAC ゼリ一製剂は以前の報告に従って調整した》．す なわち，約 $60^{\circ} \mathrm{C}$ に加温した精製水にゼラチンを溶解 し，NAC 内服液を加え混和した。次にフレーバーを添 加して溶解し, 精製水にて全量を合わせた後, 冷暗所に てゲル化させた .

矯味剤には, ゼリー, 液ともに, 以前の調査》により ミルクコーヒー味, 抹茶味に比べて最も服用しやすいと されたアップル味を選択した .

\section{2. アンケート調査}

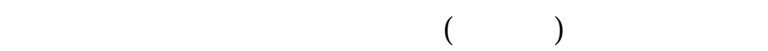
さ」の5項目について，NACゼリーの調整を始めた 2005 年 6 月から 2006 年 8 月までの間に服用した患者 35 名(男性 32 名，女性 3 名，平均年齢 70.8 歳)に対してア ンケート調査を実施した。

評価は, (1)NACゼリ一の方がとても飲みやすい, (2) NAC ゼリーの方がやや飲みやすい，(3)どちらもほぼ同 じ，(4NAC 液の方がやや飲みやすい，(5NAC 液の方が とても飲みやすい,の5段階とした .

\section{3. 評価項目}

NAC の造影剂腎症に対する予防効果を評価するため の項目としては, 造影阂投与後 48 時間以内の血清クレ アチニン值の変化率, 造影剂投与後 48 時間以内に血清 クレアチニン值の $25 \%$ 以上の上昇が生じた状態と定義 されている造影剂腎症(RCIN ; radio-contrast-induced nephropathy)の発症数, ARF(acute renal failure)の発症数 , すなわち，造影剂腎症により造影剂投与後 120 時間以内 に透析が必要だった症例数とした .

統計解析は, 患者背景では, 年齢など 2 群の平均值の 比較に対しては対応のないt検定, 男女比に対してはX² 独立性の検定, 合併症, クレアチニンクリアランス值別 の人数, 検査の種類に対しては, マン・ホイットニー検 定を用い $p<0.05$ をもって有意な差とした．また，造影 剂投与後 48 時間以内の血清クレアチニン值の変化率に 対しては対応のないt検定を, RCIN の発症数にはX²検 定を用い, $p<0.05$ をもって有意な差とした .

\section{結果および考察}

\section{1. 患者背景}

今回の検討の対象となった NAC 群，対照群の背景を 表 2 に示した . 年齢, 男女比, 合併症において, NAC 群と対照群との間に有意差はなかった．また，補液によ るハイドレーションは全症例に対して乳酸あるいは酶酸 リンゲル液を用いて行われており，投与量にも 2 群の間 に有意差はなかった . 体重あたりの造影剂の投与量も 2

表 1.NAC ゼリーおよびNAC 液の製阂組成

NACゼリ-

\begin{tabular}{|c|c|}
\hline 組 成 & 含有量 \\
\hline NAC & $600 \mathrm{mg}$ \\
\hline ゼラチン & $1.0 \mathrm{~g}$ \\
\hline フレーバー (アップル味) & $1.2 \mathrm{~g}$ \\
\hline 精製水 & 適量 \\
\hline 全量 & $10 \mathrm{~mL}$ \\
\hline
\end{tabular}

NAC液

\begin{tabular}{|c|c|}
\hline 組 成 & 含有量 \\
\hline NAC & $600 \mathrm{mg}$ \\
\hline フレーバー (アップル味) & $1.2 \mathrm{~g}$ \\
\hline 精製水 & 適量 \\
\hline 全量 & $1 \mathrm{OmL}$ \\
\hline
\end{tabular}


表 2 . 患者背景

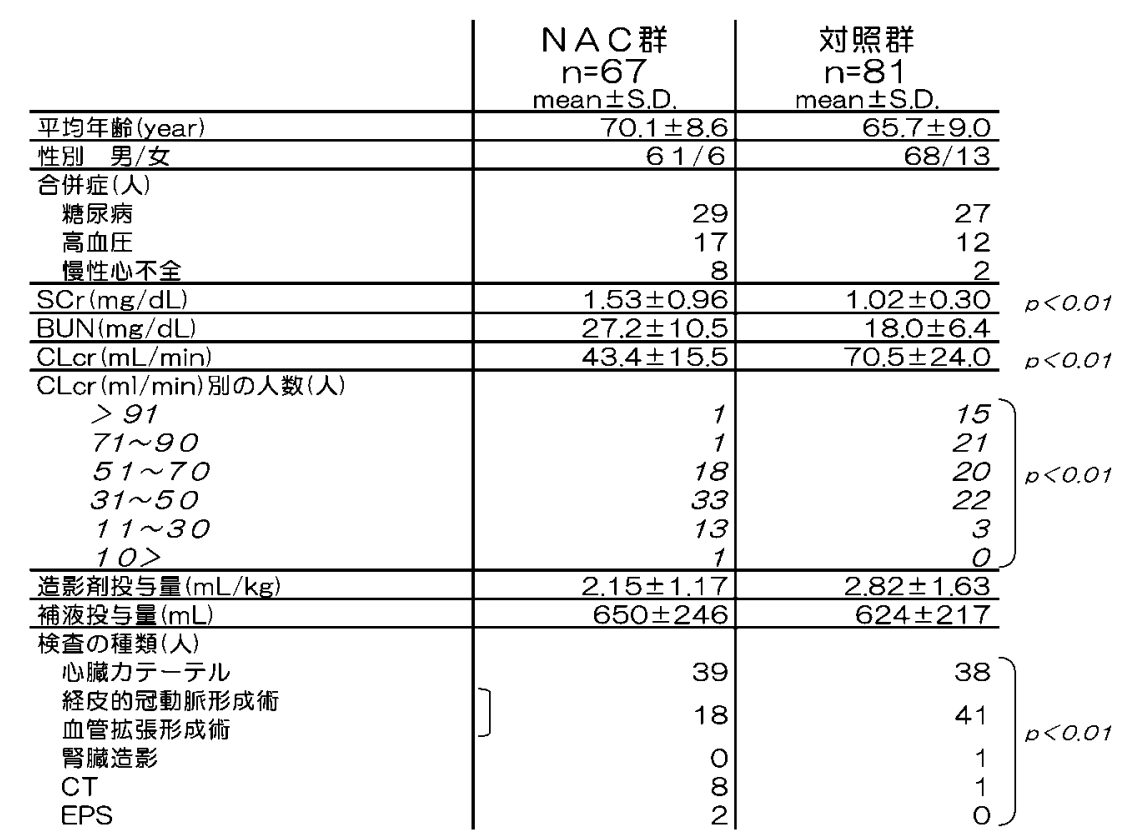

群の間に有意差はなかった .

\section{2. アンケート調査}

アンケート調査の結果(表 3)，においの項目では 100 $\%$ ，味の項目では $91 \%$ ，後味の項目では $88 \%$ の被験者 が，NAC 液に比へて NAC ゼリーの方が飲みやすいと答 えた .これらは, NAC 特有の硫黄臭の口腔内での拡散 を，ゼリー化することによって抑えることができ，さら にはアップル味の酸味によりえぐみをマスクできた結果 だと考えられ，健常成人を被験者とした以前の調査》を 裏付ける結果となった．

一方，量の項目では $86 \%$ ，飲みやすさの項目では 77 \%の被験者が, 両製剂に差はないと答えており, さらに $14 \%$ の被験者はNAC 液の方がやや飲みやすいと答え た .これらは，被験者に高齢者や男性が多く、“甘みが 気になる”“,ゼリーだとお菓子のように感じる”との意 見もあったことから，アップル味やゼリーの食感か嗜好 に合わなかったことが原因と考えられた .

これらのことから NAC をゼリー化することにより， 特異性のある硫黄臭やえぐみを改善することはできた が, 嗜好による差も認められたため, 今後は, 患者に合
わせて矯味剂を変更するなどの工夫も必要だと考えられ る。

\section{3. 造影剂投与後の血清クレアチニン値の変化}

造影剂投与後 48 時間以内の血清クレアチニン值の変 化率を比較したしたところ，NAC 群が1.91+8.47\%， 対照群が $6.85 \pm 13.83 \%$ と，NAC 群が有意に低值を示し た $(p<0.01$; 図 1). しかし, 造影剂投与前の平均血清ク レアチニン值は, NAC 群が $1.53 \pm 0.96 \mathrm{mg} / \mathrm{dL}$, 対照群 が $1.02 \pm 0.30 \mathrm{mg} / \mathrm{dL}$ と NAC 群の方が有意に高かった $(\mathrm{p}$ $<0.01$; 表 2)ことから，この值を，実測された CLcr(mL/ min)を用いて腎機能別に比較した .

谷の結果，図 2 に示したように，CLcr 31〜 $50 \mathrm{~mL} / \mathrm{min}$ と CL cr 11〜30 mL/min の患者群においては, 血清クレ アチニン值の変化率は, NAC 群が対照群に比べ有意に 低值を示した.CL cr $51 \mathrm{~mL} / \mathrm{min}$ 以上の患者においては, NAC 群と対照群との間に血清クレアチン值の変化率に 差は認められなかった .なお，CL cr $10 \mathrm{~mL} / \mathrm{min}$ 末満の 患者は, NAC 群 1名のみだったため, 図 2 には示さな かった .

表 3.アンケート集計結果(％)

\begin{tabular}{|c|c|c|c|c|c|}
\hline & $\begin{array}{c}\text { 9NACゼリーの方が } \\
\text { とても飲みかす吼 }\end{array}$ & $\begin{array}{l}\text { 2NACゼリーの方か } \\
\text { 如飲みやすい }\end{array}$ & ふど5らも同程度 & $\begin{array}{l}\text { 4NAC液の施が } \\
\text { 力か力飲ぬ切い }\end{array}$ & $\begin{array}{l}\text { 5NAC液の方が } \\
\text { とても飲列切すい }\end{array}$ \\
\hline におい & 100 & 0 & 0 & 0 & 0 \\
\hline 味 & 91.4 & 2.9 & 5.7 & 0 & 0 \\
\hline 後味 & 31.5 & 57.1 & 11.4 & 0 & 0 \\
\hline 量 (大きさ) & 0 & 2.9 & 85.7 & 11.4 & 0 \\
\hline 飲みやすさ & 2.9 & 5.7 & 77.1 & 14.3 & 0 \\
\hline
\end{tabular}




\section{RCIN 発症数}

RCIN の発症は, NAC 投与群においては認められな かったのに対し，対照群においては 81 名中の $16 \%$ にあ たる13名が発症しており，さらに光のうち3名は透析 を必要とする結果となった(図 3).

また，RCIN を引き起こす因子を検討したところ，腎 機能による差は認められなかったものの，CL cr 31〜50 $\mathrm{mL} / \mathrm{min}$ の患者群においては, 糖尿病患者の $36 \%$ にあ たる4名および高血圧患者の $67 \%$ にあたる4名が RCIN を発症した . CLCr 11〜 30 mL/min の患者群におい ては, 発症者全例において糖尿病, 高血圧か認められた (表 4).

これらのことから，糖尿病・高血圧は RCIN 発症のリ スクファクターになると考えられた . また , 低心機能 (LVEF 40\% 未満)も RCIN 発症のリスクファクターにな る可能性があると考えられた . 一方, 血清クレアチニン

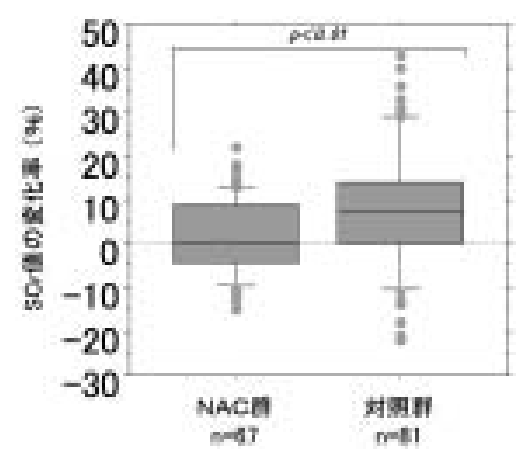

図 1. 造影剂投与後の血清クレアチニン值の変化率 箱の下端, 中央, 上端の水平線は, 光れ光れ $25 \%$ 点, $50 \%$ 点(中央值), $75 \%$ 点を表す. 垂直線(ひげ)は箱の両端から四分偏差(25\% 点 から $75 \%$ 点までの距離)の 1.5 倍以内で最も 離れた点まで引いている。
值の変化率は CLcr $30 \mathrm{~mL} / \mathrm{min}$ 以下の患者群で大きな傾 向があったものの(図 2), 発症する腎機能障害の重症度 と造影剂投与前の腎機能の程度との間に明らかな関係は 認められなかった .

NAC 群においては, 糖尿病・高血圧・低心機能を合 併している患者においても RCIN の発症は認められず (表 4), リスクファクターがある患者においても予防効 果があることが示唆された .

5. 造影剂の浸透圧の違いによる血清クレアチン值の変 化率の比較

使用された造影剂を，低浸透圧造影剂(〔0.70smol/ $\left.\mathrm{kg} \cdot \mathrm{H}_{2} \mathrm{O}\right)$, 高浸透圧造影剂 $\left(>0.70 \mathrm{smol} / \mathrm{kg} \cdot \mathrm{H}_{2} \mathrm{O}\right)$ に分 けてNAC 群, 対照群での血清クレアチニン值の変化率 を比較したところ，低浸透圧造影剂においては，両群間 での有意差は認められなかったものの, 高浸透圧造影剂

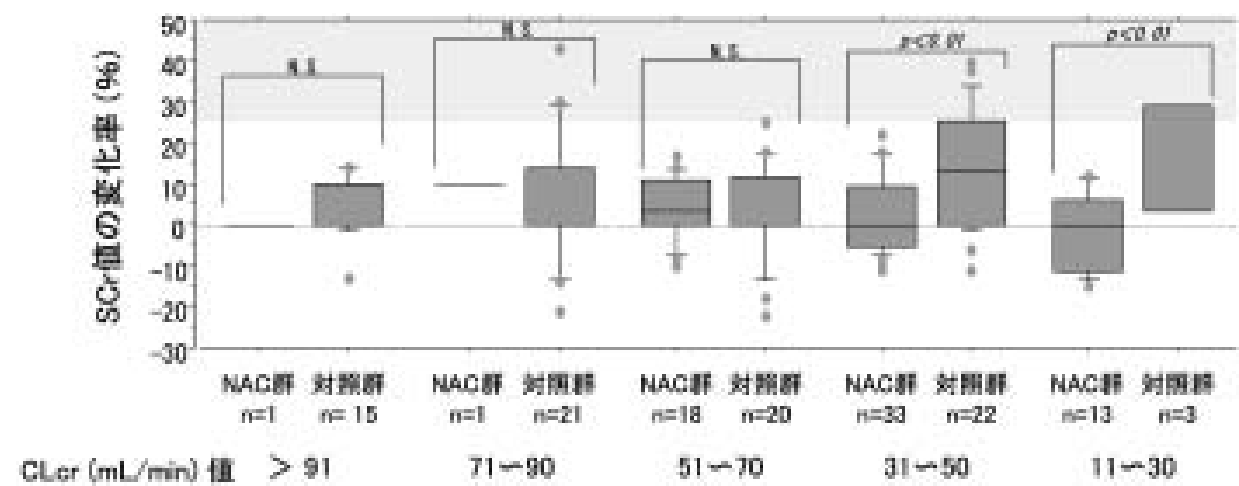

図 2. 腎機能別における造影剂投与後の血清クレアチニン值の 变化率

箱の下端，中央，上端の水平線は，光れ光れ $25 \%$ 点, 50 $\%$ 点(中央值), $75 \%$ 点を表す.垂直線(ひげ)は箱の両端 から四分偏差( $25 \%$ 点から $75 \%$ 点までの距離)の 1.5 倍以 内で最も離れた点まで引いている . 
表 4 . 腎機能·合併症別の RCIN の発症数(人)

\begin{tabular}{|c|c|c|c|c|c|c|c|c|c|c|c|}
\hline \multirow[b]{3}{*}{$\begin{array}{c}\text { CLcr值 } \\
(\mathrm{mL} / \mathrm{min})\end{array}$} & \multicolumn{4}{|c|}{ NAC群 } & \multicolumn{7}{|c|}{ 対照群 } \\
\hline & \multicolumn{3}{|c|}{ 合併症 } & \multirow{2}{*}{$\begin{array}{l}\text { RGIN発症数 } \\
\text { (症例数) }\end{array}$} & \multicolumn{3}{|c|}{ 合併症 } & \multirow{2}{*}{$\begin{array}{l}\text { RGIN発症数 } \\
\text { (症例数) }\end{array}$} & \multicolumn{3}{|c|}{ RCIN発症者の合併症 } \\
\hline & 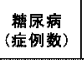 & 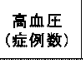 & $\begin{array}{l}\text { 低心機能 } \\
\text { (能够较) }\end{array}$ & & 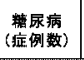 & 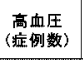 & 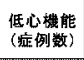 & & 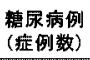 & 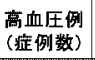 & $\begin{array}{l}\text { 低心機能 } \\
\text { (绽例数) }\end{array}$ \\
\hline$<10$ & 1 & 0 & 0 & 0 & $o$ & $o$ & 0 & 0 & $o$ & 0 & 0 \\
\hline $11 \sim 30$ & 7 & 4 & 2 & 0 & 2 & 2 & 1 & 2 & 2 & 2 & 1 \\
\hline $31 \sim 50$ & 17 & 8 & 4 & 0 & 11 & 6 & 0 & 6 & 4 & 4 & $o$ \\
\hline $51 \sim 70$ & 4 & 5 & 2 & 0 & 6 & 2 & $o$ & 1 & 1 & 0 & 0 \\
\hline $71 \sim 90$ & $o$ & $o$ & 0 & o & 3 & 7 & 1 & 4 & 1 & $o$ & 0 \\
\hline $91<$ & 0 & $o$ & 0 & $o$ & 5 & 1 & 0 & $o$ & $o$ & $o$ & 0 \\
\hline
\end{tabular}

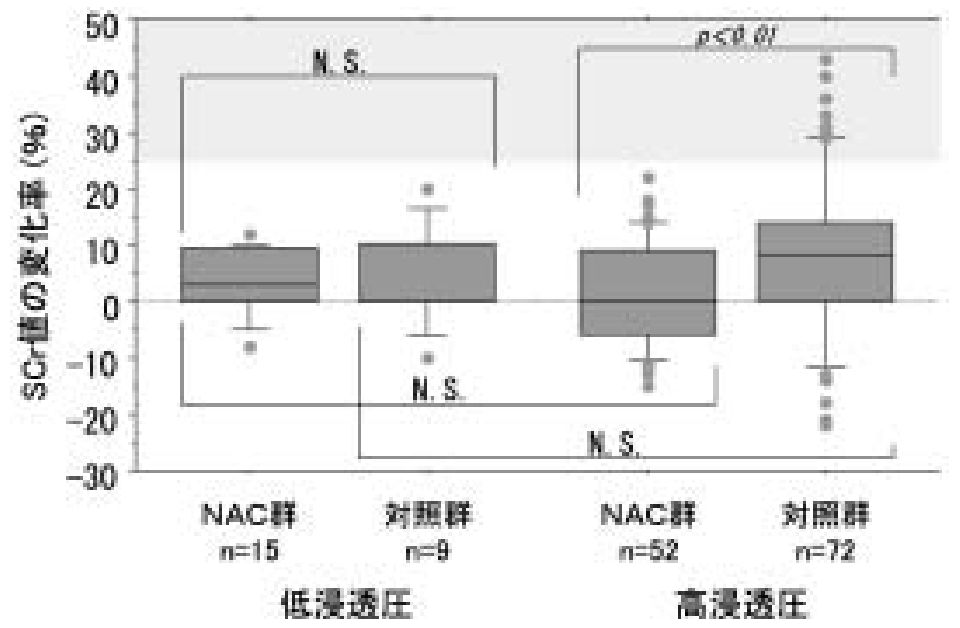

図 4 . 造影剂の浸透圧の違いによる血清クレアチニン值変化率の比較 箱の下端, 中央, 上端の水平線は, 弚れ光れ $25 \%$ 点, $50 \%$ 点(中 央值)，75\% 点を表す.垂直線(ひげ)は箱の両端から四分偏差(25 \%点から $75 \%$ 点までの距離)の 1.5 倍以内で最も離れた点まで 引いている .

においては,NAC 群が対照群に比べ, 血清クレアチニ ン值の变化率は有意に低值を示した $(p<0.01$; 図 4).

一般的に，RCIN は，高浸透圧造影阁により発症しや

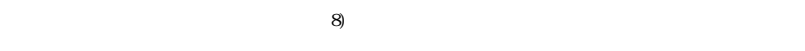
認められ，対照群の高浸透圧造影剂使用患者に高頻度で 発症した .一方，NAC 群においては，いずれの造影剂 でもRCIN の発症は認められなかった(図 4).

これらの結果より，NAC はRCIN 発症リスクが高い 高浸透圧造影剂に対しても，予防効果を有することが示 唆された .

今回の検討の結果，NAC 群において，腎障害のリス クは有意に減少したことから，NACは造影剂による有 害事象を抑え，腎機能低下を予防することが示唆され た。また，腎機能の低下した患者，糖尿病患者，高血圧 患者, 低心機能患者, 高浸透圧造影剤の使用は RCIN の
リスクファクターになり，NAC はこれらに起因する腎 機能悪化を予防できる可能性があることも示唆された .

\section{引用文献}

1) M. Tepel, M. van der Giet, C. Schwarzfeld, U. Laufer, D. Liermann, W. Zidek, Prevention of radiographiccontrast-agent-induced reductions in renal function by acetylcy steine, N. Eng. J. Med ., 343, 180-184 (2000).

2) H.S. Thomsen, S.K. Morcos, Contrast media and the kidney : European Society of Urogenical Radiology (ESUR) Guidelines, Br. J. Radiol ., 76, 513-518 (2003).

3) J. Kay, W.H. Chow, T.M. Chan, S.K. Lo, O.H. Kwok, A. Yip, L. Fan, C.H. Lee, W. Flam, A cetylcysteine for prevention of acute deterioration of renal function following elective coronary angiography and intervention, JAMA, 289, 553-558 (2003). 
4) R. Birck, S. Krzossok, F. Markowetz, P. A chnulle, F.J. W oude, C. Braun, A cetylcysteine for prevention of contrast nephropathy, Lancet, 362, 598-603 (2003).

5) S. Efrath, V. Dishy, M. A verbukh, A. Blatt, R. Krakover, J. Weisgarten, J.D. Morrow, M.C. Stein, A. Golik, The effect of $\mathrm{N}$-acetylcysteine on renal function, nitric oxide, and oxidative stress after angiography, Kidney Int., 64, 2182-2187 (2003).

6) アセチルシステイン内服液 $17.6 \%$ 「ンジュ $\left.{ }^{\circledR}\right\lrcorner$,
インタビューフォーム，千寿製薬株式会社(2002).

7) 須田範行, 新里利香, 清川真美, 金内美妃, 菅原満, 郡修徳, 宮崎勝巳, 造影剂による腎機能低下の予防 を目的としたアセチルシステインゼリーの調製と評 価，医療薬学，31, 355-359 (2005).

8) B.J. Barrett, E.J. Carlisle, Metaanalysis of the Relative Nephrotoxicity of High- and Low- Osmolality lodinated Contrast Media, Radiology, 188, 171-178 (1993). 